\title{
Mujeres en el cambio social en el siglo XX mexicano
}

\author{
María Teresa Fernández
}

\section{Ciudad de México: Siglo XXI Editores y Centro de Investigaciones y Estudios Superiores en Antropología Social CIESAS, 2014, 348 páginas.}

Mujeres en el cambio social en el siglo XX mexicano es la culminación de un largo proceso de investigación que llevó a cabo la Dra. María Teresa Fernández Aceves como epílogo a su tesis doctoral y a una vasta experiencia en trabajos dedicados a la historiografía de mujeres en México. Centrado en la historia de la participación política y cultural de cinco pioneras, el libro expone el ingreso de las mujeres al debate por una sociedad donde gocen de derechos, libertad y autonomía, tanto en México como en Hispanoamérica. Desde un renovado estudio biográfico (que enfatiza la agencia transregional y los flujos de ideas) esta investigación descubre la importante obra que realizaron Belén de Sárraga (1872-1950), Atala Apodaca (1884-1977), María Arcelia Díaz (1896-1939), Guadalupe Martínez Villanueva (1906-2002) y Guadalupe Urzúa Flores (1912-2004) a favor del impulso de las mujeres cívicas y sobre todo de la autorreflexión, autocreación y autoevaluación de ellas mismas. Estas cinco mujeres ingresaron a partidos políticos y formaron parte de directivas, fueron cacicas o gestoras, fueron activistas por las mujeres y activas opositoras de la pobreza y el sufrimiento de los otros.

El libro se estructura en seis capítulos y un apéndice (que detalla la población en condición de alfabetismo por sexo entre los años 1895 y el 2000) también incluye imágenes y una amplia revisión teórica sobre cuestiones como el género y su uso en la historiografía, la nueva historia cultural, los estudios revolucionarios y posrevolucionarios y el feminismo. En este sentido, uno de los aciertos teóricos del libro consiste en el planteamiento crítico frente a las modificaciones culturales de la primera mitad del siglo XX, que confluyen en una ampliación de la participación de las mujeres en diversos ámbitos sociales pero muchas veces como ciudadanas de segunda clase. Esta reactualización del patriarcado es el telón de fondo al activismo de las cinco pioneras aquí estudiadas. Justamente visibilizarlas teniendo presente la persistencia del modelo androcéntrico es una contribución central de este libro, que apunta a la necesaria reconstrucción genealógica de los movimientos y de las mujeres que han luchado activamente por una sociedad mejor. Por otro lado, es un libro que no prescinde de la historia en general, por lo que está conectado con los procesos sociales mayormente protagonizados por 
hombres; en estricto rigor, no es una historia solamente de mujeres sino una historia con mujeres, una historia equilibrada.

El primer capítulo del libro titulado "La mujer moderna", la política y la revolución mexicana en Guadalajara, 1910-1920 está construido a partir de un debate particular y puntual; la conferencia pronunciada por Laura Apodaca (directora de la Escuela Normal para señoritas del Estado de Jalisco) después de la llegada de los constitucionalistas a Guadalajara en octubre de 1914 en respuesta a la conferencia del estudiante Daniel Galindo. Este capítulo se articula en torno a la contraposición de la acción social de las damas católicas, sus acciones caritativas y su fuerte relación con las estructuras de poder de la institución católica, y las mujeres como Laura Apodaca que buscaron generar autonomía y ampliación de derechos políticos, mientras se desarrollaba la Revolución Mexicana. También el capítulo evalúa el objetivo político de los caudillos que recurrieron a ciertas imágenes de la mujer versus la influencia de las maestras y la noción transnacional de "mujer moderna". Este capítulo es clave para comprender los que siguen después, ya que explica en profundidad los debates en torno al rol de la mujer en la sociedad durante el siglo XIX y su operación concreta en la primera mitad del XX; esta disputa por roles más o menos activos y más o menos tradicionales es el centro de las luchas por la representación de las mujeres que buscan tres grandes actores sociales en México: la Iglesia Católica, el Estado (porfirista, revolucionario y posrevolucionario) y los movimientos feministas.

El segundo capítulo del libro está dedicado a la alucinante vida de una española naturalizada mexicana, su título es Belén de Sárraga Hernández (1872-1950): Anticlericalismo, libre pensamiento y la revolución mexicana (1910-1940). La vida de esta viajera, autora y conferencista que fue escuchada por miles y miles de personas en toda América Latina y que contribuyó enormemente a la articulación de movimientos políticos es todavía en gran parte desconocida. Como bien señala la Dra. Fernández, reconstruir la biografía de Belén de Sárraga, su itinerario e ideario político es una tarea titánica, ya que fundamentalmente hay que adentrarse en archivos dispersos por más de una decena de países y en una compleja red teórica que nutrió a la viajera, sin embargo, es una tarea que vale la pena y que la Dra. Fernández ha logrado de manera destacada'. En síntesis podemos señalar que Belén de Sárraga revoluciona al continente con sus propuestas anticlericales que además enfatizan la emancipación de la mujer y la organización sindical. México fue su segunda patria (país al que llegó en 1912), y fue aquí donde tuvo el acogimiento que España no le dio.

La estadía de Belén de Sárraga en Chile, y en otros países de América Latina, ha sido ampliamente trabajada por la historiadora Julia Antivilo. 
En el tercer capítulo, titulado Atala Apodaca Anaya (1884-1977): Anticlericalismo, educación cívica, fuerzas progresistas y la revolución mexicana, la Dra. Fernández analiza la vida de la maestra llamada "la Sárraga de Guadalajara" y sus contribuciones críticas en contra del discurso de género promovido por la Iglesia Católica y por el nuevo Estado revolucionario, ya que ambas instituciones tenían en común una concepción pasiva y apolítica de las mujeres. En este capítulo, la autora explica la convergencia de estas visiones y su preservación en cierto tipo de discurso historiográfico que excluye el rol tremendamente político e intelectual de muchas mujeres laicas en la educación y la búsqueda de justicia social. Como bien señala el título de este capítulo la unión de fuerzas progresistas en el decenio de 1910 es clave para comprender las acciones de Atala Apodaca a favor de la organización de los trabajadores y de la defensa de los derechos de las mujeres. Así ocurre también con su posterior ingreso al Partido Popular Socialista durante las décadas de 1940 y 1970, y con sus profundos lazos con la masonería.

El cuarto capítulo del libro se titula María Arcelia Díaz (1896-1939), la política laboral y de mujeres en el contexto de la construcción del Estado Posrevolucionario en Guadalajara. A partir de una atractiva anécdota (el acuerdo de una asamblea para asesinar a la "bolchevique" María Arcelia Díaz) la Dra. Fernández nos introduce en la reconstrucción de las huellas que dejó la vida de esta trabajadora textil. También se analiza el empoderamiento de esta pionera (entre obrera y mujer moderna) para llegar a comprender su simbolismo dentro de la memoria cultural que logró convertirla en un ícono y mito del movimiento de trabajadoras, así se contrasta la memoria construida con las fuentes y hechos realmente acaecidos.

El quinto capítulo María Guadalupe Martínez Villanueva (1906-2002): Las movilizaciones de mujeres y la política corporativa corrige la idea que entiende a esta mujer como una aventurada en política gracias a su esposo, mediante un estudio fundamentado de su trayectoria que tuvo como objetivo una política conservadora de control y sometimiento de los trabajadores con el fin de lograr un desarrollo económico y estabilidad política a favor del cacicazgo de Heliodoro Hernández Loza. El estudio de la mediación de estos dos caciques entre las bases y sus superiores permite comprender por qué por lo general no se considera a las mujeres en los estudios sobre cacicazgo y las consecuencias sociales del liderazgo de una mujer.

Finalmente, el sexto y último capítulo, se titula Guadalupe Urzúa Flores (1912-2004), gestora y modernizadora en la política campesina jalisciense. Aquí la Dra. Fernández conecta la vida de esta destacada pionera y gestora con el proceso de modernización posrevolucionario y el "milagro mexicano" en un contexto de cambios amplios. Se analiza un tipo de liderazgo (que no es el de una cacica) que buscaba representar a 
los campesinos y a las mujeres, con una fuerte base social fundada en el carisma y el bien común.

Este libro orientará a los lectores en términos amplios y generales en la problematización del ingreso de las mujeres a los principales debates en la primera mitad del siglo XX; la relación con ideologías como la masonería o el catolicismo, el trabajo asalariado, el Estado y sus aparatos, la educación y la construcción de movimientos sociales. También es un aporte para quienes busquen datos biográficos específicos sobre estas cinco pioneras, ya que la acuciosa revisión de archivos y fuentes (que van desde epistolarios, entrevistas, imágenes, canciones, poemas, hasta las memorias y fuentes tradicionales como la prensa y los archivos judiciales) disponibles impacta en datos certeros y confiables.

Carla Ulloa Inostroza ${ }^{2}$

2 Profesora de Historia, Geografía y Ciencias Sociales por la Pontificia Universidad Católica de Valparaíso, Magíster en Estudios Latinoamericanos por la Universidad de Chile y estudiante de Doctorado en Estudios Latinoamericanos en la Universidad Nacional Autónoma de México. Becaria CONACYT-México y Editora del sitio web Mujeres Viajeras. http:// historiasmujeresviajeras.blogspot.com 